\title{
Medical History Modified Reported Term
}

National Cancer Institute

\section{Source}

National Cancer Institute. Medical History Modified Reported Term. NCI Thesaurus.

Code C83333.

An indication or description of a change in medical history. 